\title{
Direct Distribution of Rents and the Resource Curse in Iran: A Micro-econometric Analysis
}

\author{
Mohammad Reza Farzanegan \\ Mohammad Habibpour
}

\author{
CESIFO WORKING PAPER NO. 4824 \\ CATEgORY 10: ENERGY AND ClimATE ECONOMICS \\ JUNE 2014
}

An electronic version of the paper may be downloaded

- from the SSRN website:

- from the RePEc website:

- from the CESifo website:

WwW.SSRN.com

Www.RePEc.org

www.CESifo-group.org/wp

\section{CESifo}




\title{
Direct Distribution of Rents and the Resource Curse in Iran: A Micro-econometric Analysis
}

\begin{abstract}
Our goal is to examine the income inequality and welfare effects of the direct distribution of resource rents and subsequent taxation in Iran. We use rich micro survey data covering more than 36,000 Iranian households in 2009. Our micro-simulations show that the direct distribution of resource rents among all citizens and the imposition of an additional direct income tax have a significant negative effect on the household GINI index and on poverty. We also examine three alternative policies to the resource dividend (RD) policy. The results show that the RD policy is the most successful policy for addressing rents-induced inequality.

JEL-Code: Q320, Q380, Q430, I300, C150.
\end{abstract}

Keywords: resource curse, direct rents distribution, poverty, inequality, household survey, Iran.

\author{
Mohammad Reza Farzanegan \\ Philipps-University of Marburg \\ Center for Near and Middle Eastern \\ Studies (CNMS) \\ Marburg / Germany \\ farzanegan@uni-marburg.de
}

\author{
Mohammad Habibpour \\ Philipps-University of Marburg \\ Center for Near and Middle Eastern \\ Studies (CNMS) \\ Marburg / Germany \\ m.habibpour@staff.uni-marburg.de
}

21 May 2014

We thank Peren Arin, Kjetil Bjorvatn, Mohammad Khabbazan, Christian Neugebauer, Elisabeth Schulte, Marcel Thum and participants at the MACIE Brown Bag seminar (2014, Marburg) for their useful comments. 


\section{Introduction}

There is abundant literature on the curse of natural resources that indicates that, on average, countries with a higher dependence on specific types of natural resources (e.g., oil, gas and minerals) show a slower economic growth rate than resource-poor countries over the long run ${ }^{1}$. There are several plausible transmission channels of the resource curse to economic development, such as Dutch disease (van Wijenbergen, 1984), weaker investment in human capital (Gylfason, 2001), fragile political and economic institutions, rent-seeking and corruption (Mehlum et al., 2006, Torvik, 2002, Bjorvatn and Selvik, 2008), marginalized entrepreneurship activities (Farzanegan, 2014), increased probability of a demographic curse (Bjorvatn and Farzanegan, 2013) and conflict (Ross, 2004; Collier and Hoeffler, 1998 and 2004). Some studies have shown that the possibility of experiencing the resource curse is greater in factional societies and polities (Montalvo and Reynal-Querol, 2005; Hodler, 2006; Bjorvatn, Farzanegan and Schneider, 2012 and 2013). Inequality effects of resource-based economies have also been investigated in cross-country studies. For example, Fum and Hodler (2010) show that natural resource rents increase income inequality in ethnically fractionalized countries, while in ethnically divided societies, resource rents encourage rent-seeking and destructive competition in which only one group benefits from the rents. This group becomes richer while the others become poorer. The game leads to an increased income gap in a divided society. In a homogenous country such as Norway, however, resource rents redistribution seems to be more equal (Alesina and Glaeser, 2004). Our analysis focuses on the case study of Iran, an ethnically divided society and one of the major producers and exporters of crude oil in the world.

In this study, we use a rich survey of Iranian urban and rural households to simulate the effect of direct distribution of resource rents on income inequality and poverty. Resource-rich nondemocratic countries have a higher tendency to spend and distribute the resource revenues on the basis of patronage, buying the political loyalty of a small but powerful group of society (e.g., military and security) (see Dizaji and Farzanegan, 2014). ${ }^{2}$ The unequal distribution of resource rents in resource-rich countries is one of the major drivers of internal conflict and political instability. Collier et al. (2003) and Chamarbagwala and Moran (2011) for the case of Guatemala and Shemyakina (2011) for the case of Tajikistan provide a detailed analysis of the

\footnotetext{
${ }^{1}$ For general surveys of related literature, see Ross, 2012, van der Ploeg, 2011 and Frankel, 2010

${ }^{2}$ We examined the association between different kinds of natural resource rents (\% of GDP) and share of military spending in GDP for more than 150 countries from 1988 to 2010. Resource rents dependency (with a one-year lag) has a significant increasing association with current military burden, controlling for country and time fixed effects. The increasing effect is more evident for oil and mineral rich economies.
} 
economic and human costs of conflict. The literature suggests different policy options to address the curse of resources, such as implementing political decentralization (Farzanegan, Lessmann, and Markward, 2013). Some of the literature recommends the direct distribution of resource rents as a remedy for the resource curse. This latter suggestion is based primarily on a qualitative evaluation of different case studies.

The micro-simulation conducted using the unique large household survey in developing and resource-rich countries provides empirical evidence for the constructive role of direct rents distribution and the introduction of new income taxation in addressing poverty and inequality. The case study of Iran is clearly justified by the significant position of natural resource rents in its political economy. On average, from 1960 to 2012, 80\% of Iran's total exports depend on oil and gas. The direct dependence of the government budget on oil revenues from 1965 to 2010 was, on average, 56\%, while the average share of tax revenues in total government revenues for 1970 to 2010 was 32\% (for more details on the oil macro-economy of Iran nexus, see Farzanegan and Markwardt, 2009; Farzanegan, 2011, Farzanegan, 2013, and Mohaddes and Pesaran 2013).

The remainder of this paper is structured as follows. Section 2 presents empirical evidence on the strong association between oil rents and income inequality in Iran at the macro level. In Section 3, we discuss a relevant part of the literature that suggests the distribution of oil rents as a policy to address resource rents-induced inequality. Section 4 explains the data, the microsimulation methodology and the main results. Section 5 concludes the paper.

\section{Inequality and oil rents in Iran: macro evidence}

Fum and Hodler (2010) provide empirical evidence of the inequality effects of income rents using a global sample. The question is, does such a problem exist in Iran? ${ }^{3}$ Given that the proposal of this study is how to address inequality and poverty through different distribution policies of oil rents in Iran, we should first provide some evidence of inequality effects due to increasing oil rents. Accordingly, we use the vector autoregressive (VAR) model to estimate the impulse response function (IRF) with annual time series data from GINI, real oil rents per capita and real GDP per capita from 1969 to 2010 in Iran. We aim to see how the GINI index responds to increasing shocks in a logarithm of oil rents per capita while controlling for the logarithm of income per capita in Iran. Data are taken from the CBI (2014).

\footnotetext{
${ }^{3}$ Poverty and inequality are the central issues of political discussions in Iran since Islamic revolution (for an analytical review of income inequality and poverty in post-revolutionary Iran see Salehi-Isfahani (2009).
} 
In the VAR model, changes in a particular variable are related to changes in the variable's own lags and to changes in the lags of other variables in the system:

$$
y_{t}=A_{1} y_{t-1}+\cdots+A_{p} y_{t-p}+B x_{t}+\varepsilon_{t}
$$

where $y_{t}$ represents a vector of $k$ endogenous variables (GINI, $\log$ (GDP per capita) and $\log$ (oil rents per capita)); $x_{t}$ is a vector of $d$ exogenous variables (constant, dummy variable for war period in Iraq:1980-1988 and post-revolution period:1979-2010); $A_{1}, \ldots, A_{p}$ and $B$ are matrices of coefficients to be estimated; $p$ is the optimum lag order and $\varepsilon_{t}$ is a vector of innovations that may be contemporaneously correlated but are uncorrelated both with their own lagged values and with all of the right-hand side variables. All endogenous variables are $I(1)$, and there is one cointegeration relationship among them (using the Johansen and Juselius1990 approach). We use an unrestricted VAR model in levels of variables. Sims (1980), Sims, Stock and Watson (1990), and Doan (2000) recommend against differencing the cointegrated variables in the VAR estimations. In this study, we are interested in impulse responses rather than estimated coefficients in the VAR models ${ }^{4}$. Furthermore, the literature suggests that in the short run, unrestricted VAR simulations outperform vector error correction model forecasts ${ }^{5}$.

We are interested in the direction and the statistical significance of the GINI response to a one standard deviation increasing shock to the log of oil rents per capita. The ordering of variables in the VAR system is important for calculating the IRF. We use generalized impulse responses that are not sensitive to the ordering of variables (Pesaran and Shin, 1998). We use the Monte Carlo method with 1000 repetitions to calculate impulse response standard errors at 95\% confidence intervals. On the basis of the AIC (Akaike information criterion), we use 4 years as the optimum lag length for our VAR model. The VAR stability condition check also indicates that the estimated VAR is stable (stationary) if all roots have modulus less than one and lie inside the unit circle ${ }^{6}$. Thus, impulse response standard errors are valid. Furthermore, we examine residual serial correlation up to the 12 lag order. The results of the autocorrelation Lagrange Multiplier (LM) test (Johansen, 1995, p. 22) show that there is no serial correlation in estimated VAR residuals. ${ }^{7}$ Figure 1 shows the response of the GINI to a one standard deviation increasing shock to the logarithm of oil rents per capita while controlling for the logarithm of income per capita. The short run response after the initial oil shock is positive and statistically

\footnotetext{
${ }^{4}$ See also Farzanegan and Markwardt, 2009; Farzanegan, 2011 and 2012; Dizaji and Bergeijk, 2013 and Dizaji and Farzanegan, 2014 for the similar approach in using VAR in levels.

${ }^{5}$ For more details see Naka and Tufte, 1997; Engle and Yoo, 1987, Clements and Hendry, 1995 and Hoffman and Rasche, 1996

${ }^{6}$ See Lütkepohl , 1991 for more details on this test

${ }^{7}$ Results are available upon request.
} 
significant at a 95\% confidence interval for the first 2 years after shock. This is a strong indicator of income inequality increases after increasing oil rents shocks in Iran. The GINI response and its significance are robust if we also use the logarithm of oil rents as a share of the GDP (instead of per capita term).

Figure 1. Response of GINI to one standard deviation increasing shock in oil rents per capita Response of GINI to log of Oil Rents per capita

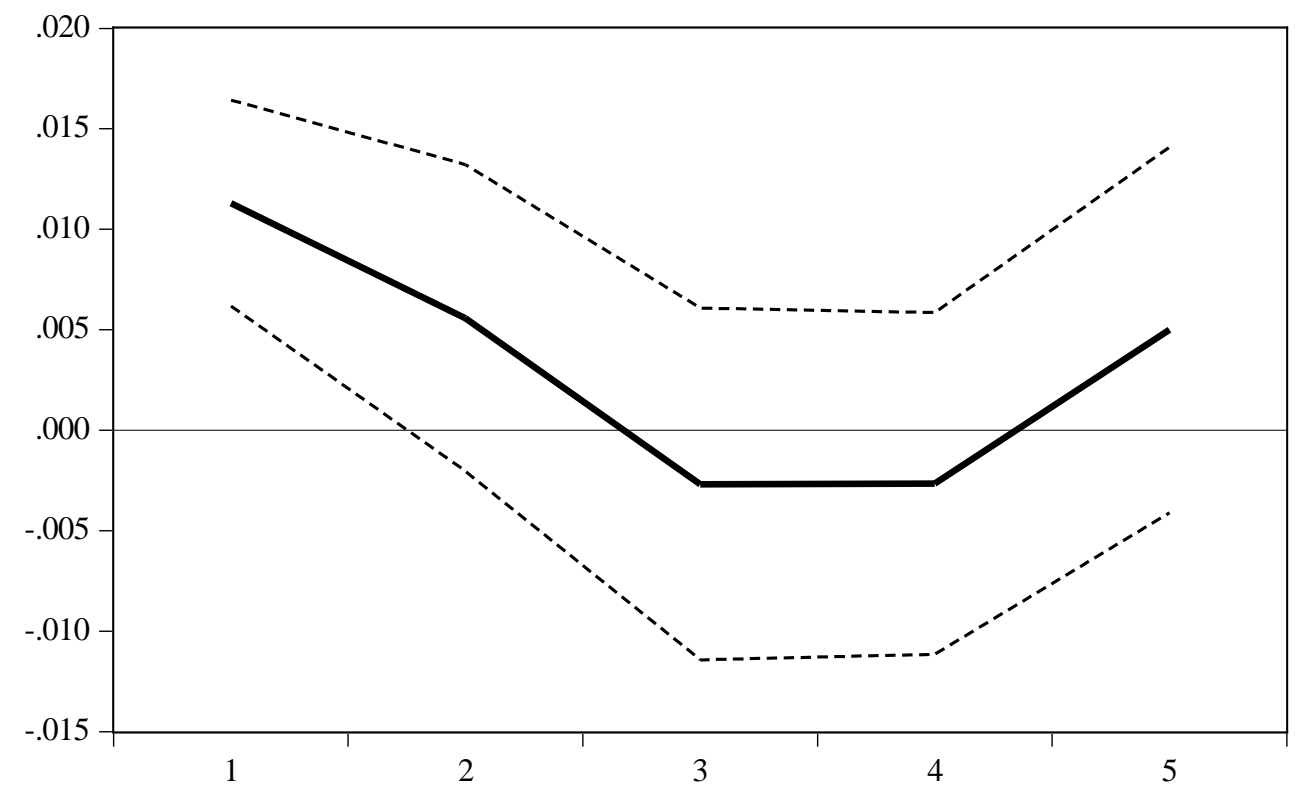

Note: horizontal axis shows number of years after initial oil shock and vertical axis shows the magnitude of responses in GINI to oil shocks. Dashed lines shows \pm 2 S.E. of impulse response.

To determine the relative importance of oil rents shocks in changes of the GINI (and income per capita) in the VAR system, we apply the variance decomposition analysis (VDA), which shows the percentage of change in a specific variable (e.g., GINI) in connection with its own shock against the shocks to other variables (e.g., oil rents and income per capita). The higher the share of the explanation of a particular variable (such as GINI), the more important the variable.

Table 1 shows the VDA results. Oil shocks have the major explanatory power in explaining the variance of the GINI index in the short and long run. Approximately $48 \%$ of the variance of the GINI in the first year following the initial shock can be explained by changes in oil rents per capita, while the GDP per capita explains approximately 7\%. The power of oil rents in predicting the future variance of GINI increases to $49 \%$ in the $6^{\text {th }}$ year after the shock, and remains at approximately $46 \%$ until the $10^{\text {th }}$ year following the initial shock. 
Table 1. Variance decomposition for GINI in Iran

\begin{tabular}{cccc}
\hline \hline & \multicolumn{2}{c}{ Varaince decomposition of GINI } \\
\hline Years ahead & $\log$ (oil rents per capita) & $\log$ (GDP per capita) & GINI \\
1 & 48.11 & 7.55 & 44.34 \\
2 & 47.02 & 6.03 & 46.95 \\
3 & 43.99 & 5.93 & 50.08 \\
4 & 44.39 & 7.00 & 48.61 \\
5 & 47.44 & 6.87 & 45.69 \\
6 & 49.01 & 6.69 & 44.30 \\
7 & 47.23 & 9.15 & 43.62 \\
8 & 47.62 & 9.93 & 42.45 \\
9 & 46.83 & 11.42 & 41.75 \\
10 & 46.06 & 12.32 & 41.62 \\
\hline \hline
\end{tabular}

Note: estimation sample period is 1969-2010. We use Cholesky ordering of oil rents, GDP per capita and GINI.

In summary, there is empirical evidence regarding the significant role of oil rents in increasing the income gap in Iran. In the rest of this paper, we discuss our proposal to address one of the dimensions of the resource curse in Iran.

\section{Review of the resource rents distribution literature}

A direct equal transfer of the natural resource rents to all citizens has been proposed by several authors as a solution of the resource curse. Sala-i-Martín and Subramanian (2003) suggest that corruption in the resource rents management better explains the poor economic growth of Nigeria than does Dutch disease. To address the increasing corruption in the oil-rich economy of Nigeria and the enhancement in the quality of public institutions, they suggest a direct equal transfer of oil revenues to the public. They also propose similar recommendations for other countries that are dealing with a resource curse, especially Iraq and Venezuela. Clemons (2003) argues that $\$ 8$ billion of Iraq's annual oil revenue can be managed as an Iraq permanent fund and be distributed directly to Iraq's six million households, which would make a substantial difference to those families whose per capita GDP is only \$2,500. Again, in the case of Iraq, Palley (2003) suggests a modified version of Clemons' proposal whereby a trust fund is created to distribute $25 \%$ of Iraq's oil revenue directly to every citizen. He also proposes an additional foundation to allocate shares of oil revenues to local governments to avoid any potential regional protests.

Sandbu (2006) recommends a national wealth account to collect the resource rents and transfer them directly to the people and then tax the rents. He explains that the policy has three important benefits. First, there are income effects generated by increasing the income level of 
the people; second, there are information effects that provide a better understanding of resource wealth based on a per capita term rather than a great government scale of the budget; third, there are endowment effects that increase participation of the public in questioning the governments about the resource rents related fiscal policies.

Segal (2011) explains that if every country directly transfers the rents to every adult citizen on an equal basis, then global poverty would be reduced by half, which is in the first Millennium Development Goal, and this can happen independent of aggregate growth. He uses the World Bank data covering 15 different natural resources for 115 developing resource-rich and resource-poor countries. His finding shows that the percentage of the world's poor population decreases from 25.6 to 8.6 between 2005 and 2006 without extra taxation. This is a 66 percent reduction in the extreme poverty rates of developing countries. In the case of imposing a proportional income tax, the world's poor population would reach 11.2 percent, which is still a 56 percent reduction in extreme poverty.

We add to the literature by using a unique large household survey and providing new empirical evidence for constructive effects of the direct distribution of resource rents on addressing inequality and poverty in one of the leading resource-rich economies, i.e., Iran. We also compare the main proposal (direct distribution of rents and subsequent taxation) with other possible policies and discuss their performance on inequality, poverty and the welfare of households in Iran.

\section{Data, methodology and simulation results}

We implement a micro simulation to predict the policy effects of resource rents distribution on income inequality, the poverty level, and social welfare in Iran. We use survey-based micro data provided by the National Statistical Center of Iran from 2009 that cover approximately 140,000 individuals including over 36,000 urban and rural households ${ }^{8}$. We divide the total natural resource rents in Iran in 2009 by the population and add it to every citizen's income. We also levy a tax at a rate that compensates for a possible reduction of the government revenues from natural resource rents to keep the government budget constraint unchanged and to avoid further monetary problems, such as budget deficit-induced inflation.

It is assumed that total disposable income covers both taxable and non-taxable incomes. The household survey data contain seven sources of income. Three of these sources are taxable

\footnotetext{
${ }^{8}$ The questionnaire (in Farsi) is available on the website of the Iran Statistical Center: http://www.amar.org.ir/Portals/0/info-unit/Files/hazineh-daramad-doc-1388.pdf. The raw survey data are available at the Iran Statistical Center (Tehran).
} 
incomes: income from regular salary $\left(\mathrm{y}_{1}\right)$; income from self-employed jobs $\left(\mathrm{y}_{2}\right)$; and income from the resource rents, which are mainly the rents from land and real estate $\left(\mathrm{y}_{3}\right)$. Nontaxable incomes are comprised of retirement salaries, government transfers to households, revenues from saving accounts and other sources of income. Eq. 2 presents the calculation of disposable income:

$y^{d}=C+\left[\left(1-t_{1}\right) y_{1}+\left(1-t_{2}\right) y_{2}+\left(1-t_{3}\right)\left(y_{3}+R D\right)\right]\left(1-t_{4}\right)$

where $y^{d}$ is disposable incomes; $C$ is exogenous incomes; $t_{1}, t_{2}$ and $t_{3}$ are taxes that are already levied before the simulation; $R D$ is the resource rents dividends; and $t_{4}$ is the extra simulated levied tax.

To divide the resource rents directly among all citizens, we note that a huge part of the rents are a prominent income source for the government of Iran. Excluding this source of income from the government budget could cause a budget deficit that may force the State to supply fiat money and thus promote inflation. To avoid a budget deficit for the State, we impose a tax on taxable incomes, which leads to an amount equivalent to the share of the resource rents in the total government budget.

In 2009, the total GDP of Iran was 3,252,759 ${ }^{9}$ billion Rials (approximately $\$ 363$ billion). Natural resource rents as a share of Iranian GDP in 2009 were $31 \%{ }^{10}$. Given the total population of 73,542,954, we calculate the per capita resource rents and determine that resource rents comprise approximately $60 \%$ of the government's budget, which is $18 \%$ of the GDP ${ }^{11}$. We add resource rents dividends to the income from resource rents $\left(\mathrm{y}_{3}\right)$ and impose an $18 \%$ tax $\left(t_{4}\right)$ on the households' incomes to offset the excluded rent income in the government's budget.

In this study, our aim is to assess the resource dividend (RD) policy. However, we also examine three alternatives to this policy.

First, we examine a policy that redistributes the resource rents of the government, i.e., resource dividends from government sources (RDG). In our case, these resource rents comprise $18 \%$ of the GDP, while the total resource rents are 31\% of the GDP. We equally distribute these rents to all citizens and tax them at a rate of $18 \%$ of their taxable incomes. In alternative policies, the total amount of taxes levied on the population is equal to the total amount of resource rents

\footnotetext{
${ }^{9}$ National Accounts, National Statistic Center. Available at http://www.amar.org.ir/Default.aspx?tabid=104.

${ }^{10}$ See World Bank (2014). Based on the World Bank definition: total natural resource rents are the sum of oil rents, natural gas rents, coal rents (hard and soft), mineral rents, and forest rents. See http://data.worldbank.org/indicator/NY.GDP.TOTL.RT.ZS

${ }^{11}$ Data on Iranian government finance is available at http://www.cbi.ir/page/4488.aspx.
} 
distributed. The difference in the RD policy is that a lesser amount of the resource rents is distributed under the RDG policy.

Second, we examine a targeted policy that transfers resource rents only to the households that are below the poverty line, i.e., resource dividends for the poor (RDP). In our case, if we want to cover all households that are below the poverty line, we need to finance the policy with the resource rents equal to 3\% of the GDP and levy a 3\% tax only on the households above the poverty line ${ }^{12}$.

Third, we explore a guaranteed minimum income (GMI) policy that fills the gap between income below the poverty line and the poverty line. As a result, the amount transferred to each household depends on their total income, and the gap between their income and the poverty line is covered by a transfer. To finance this policy, resource rents must equal $1 \%$ of the GDP; we then impose a $1 \%$ tax on households above the poverty line.

RDP and GMI policies are as follows:

$\begin{cases}y^{d}=C+R D+\left(1-t_{1}\right) y_{1}+\left(1-t_{2}\right) y_{2}+\left(1-t_{3}\right)\left(y_{3}\right) & y \leq \bar{y} \\ y^{d}=C+\left[\left(1-t_{1}\right) y_{1}+\left(1-t_{2}\right) y_{2}+\left(1-t_{3}\right)\left(y_{3}\right)\right]\left(1-t_{4}\right) & \bar{y}<y\end{cases}$

where $\bar{y}$ is the poverty line and $\mathrm{RD}$ is $y-\bar{y}$ in guaranteed minimum income (GMI) policy.

To assess the policy effects of the direct distribution of resource rents on poverty and inequality, we use different poverty indices and the GINI decomposition. The poverty line is defined as half of the median of the total households' incomes. As this poverty line is significantly higher in urban areas, we separate the measurements for the urban areas and the rural areas.

Based on the poverty line $(z)$, we measure the poverty gap index (PGI) to determine the degree to which, on average, households are below the poverty line before and after the policy. The poverty gap index is presented as a percentage of the poverty line and is measures as ${ }^{13}$ :

$P G I=\frac{1}{N} \sum_{j=1}^{q}\left(\frac{z-y_{i}}{z}\right)$

\footnotetext{
${ }^{12}$ This 3\% rate for the RDP and the 1\% rate for the GMI are gained from our calculations in the sample. These calculations are based on the total resource rents that are allocated to the households.

${ }^{13}$ Poverty measurements and their expressions in our estimations are obtained from the World Bank Institute poverty manual, 2005, which is available at http://siteresources.worldbank.org/PGLP/Resources/PovertyManual.pdf
} 
Moreover, we estimate two distribution-sensitive poverty indices, the Watts index $(W)$ and the Sen index, to gain a better intuition of the policy effects. These take the following forms:

$W=\frac{1}{N} \sum_{j=1}^{N} \ln \left(\frac{z}{y_{j}}\right)$

We estimate the Sen Index using the poverty gap index, the poverty line $(H)$ and the GINI coefficient of the households below the poverty line:

Sen index $=H *$ Gini $+P G I(1-G i n i)$

The results are shown in the Table 2.

The most successful policy for eradicating poverty is the GMI policy, which requires a $1 \%$ tax to be levied on taxable incomes. This tax compensates the rent revenues that are a source of the government's income before distributing the revenues to the poor. However, only $24 \%$ of the households would be better off after the GMI. Thus, while the results show that targeting policies such as RDP and GMI are better in addressing poverty, the income winners are equal to the share of poor households in total population.

Table 2. Changes in the population share below the poverty line

\begin{tabular}{cccccccc}
\hline \hline District & Policy Status & $\begin{array}{c}\text { Headcount } \\
\text { ratio } \%\end{array}$ & $\begin{array}{c}\text { Poverty gap } \\
\text { ratio } \%\end{array}$ & $\begin{array}{c}\text { Income gap } \\
\text { ratio \% }\end{array}$ & $\begin{array}{c}\text { Watts } \\
\text { index }\end{array}$ & $\begin{array}{c}\text { Sen index } \\
* \mathbf{1 0 0}\end{array}$ & $\begin{array}{c}\text { Income } \\
\text { Winners }\end{array}$ \\
\hline Rural & Current Policy & 24 & 10.4 & 43 & 16.8 & 13.8 & \\
& RD & $14.8^{*}$ & 4.4 & 30 & 5.8 & 6 & $\mathbf{9 9 \%}$ \\
& RDG & 14.8 & 4.6 & 31 & 6.2 & 6.3 & $\mathbf{9 6 \%}$ \\
& RDP & 11 & 1.7 & 16 & 2 & 2.5 & $\mathbf{2 4 \%}$ \\
& GMI & 0.00 & 0.00 & 0.00 & 0.00 & 0.00 & $\mathbf{2 4 \%}$ \\
\hline Urban & Current Policy & 17 & 7.7 & 44.4 & 13 & 10.3 & \\
& RD & $10.8 *$ & 3.2 & 30 & 4.4 & 4.5 & $\mathbf{9 7 . 5 \%}$ \\
& RDG & 11.5 & 3.7 & 31.8 & 5.1 & 7.1 & $\mathbf{9 2 \%}$ \\
& RDP & 6.7 & 1.5 & 22.5 & 1.9 & 2.2 & $\mathbf{1 8 . 5 \%}$ \\
& GMI & 0.00 & 0.00 & 0.00 & 0.00 & 0.00 & $\mathbf{1 7 \%}$ \\
\hline \hline
\end{tabular}

Note: * considering the poverty line before the policy the Headcount ratio would decrease from $24 \%$ to $0.4 \%$ for the rural households and from $17 \%$ to $3 \%$ for the urban households. 
Based on the results before the direct distribution of resource rents (RD), $24 \%$ of the households in the rural areas were below the poverty line, while after receiving the resource dividends and payments from the 18\% direct income tax, the population below the poverty line decreased by $\mathbf{3 8 \%}$. In the urban areas, the population share below the poverty line is $17 \%$, which is less than that of the rural areas. By implementing direct rents distribution (RD) and income taxation, the share of the population below the poverty line decreases to $10.8 \%$, which is a $\mathbf{3 6 \%}$ reduction. The income winners' percentage (households whose incomes increased after the policy) in both areas are significantly high, which suggests the possibility of public support for the proposed policy. The poverty gap is reduced by half, which indicates a reduction in the distance between poor income and the poverty line, thus making it easier to raise the poor households out of poverty or to, at least, close the poverty gap.

Figure 2. Poverty Gap in the rural
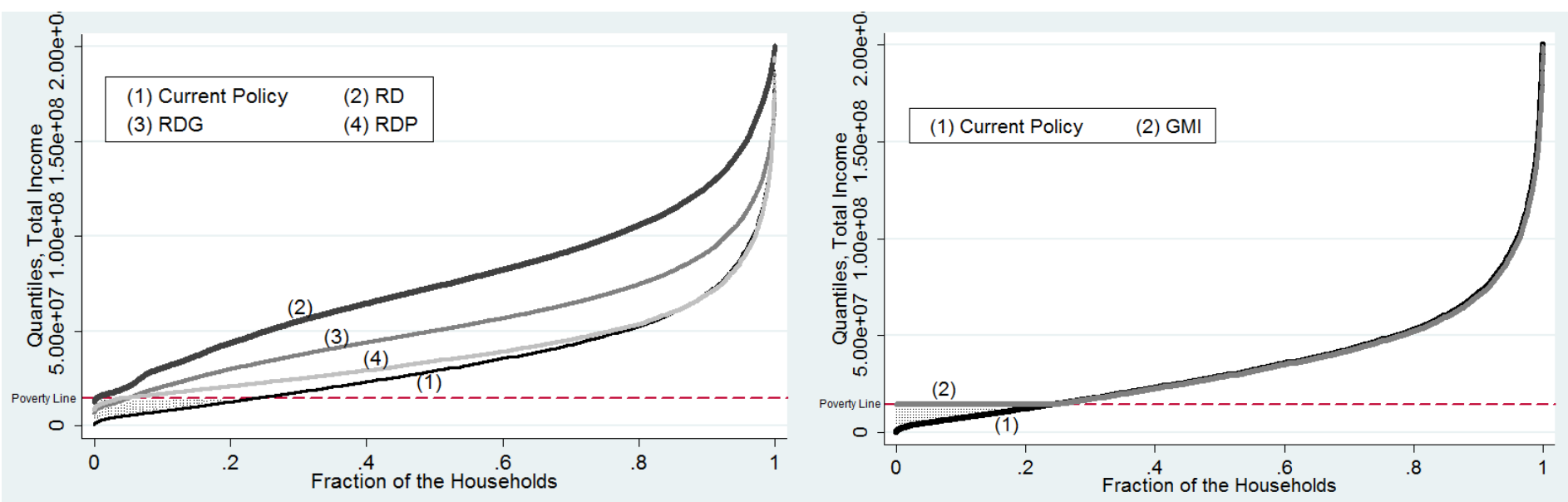

Figure 3. Poverty Gap in the urban
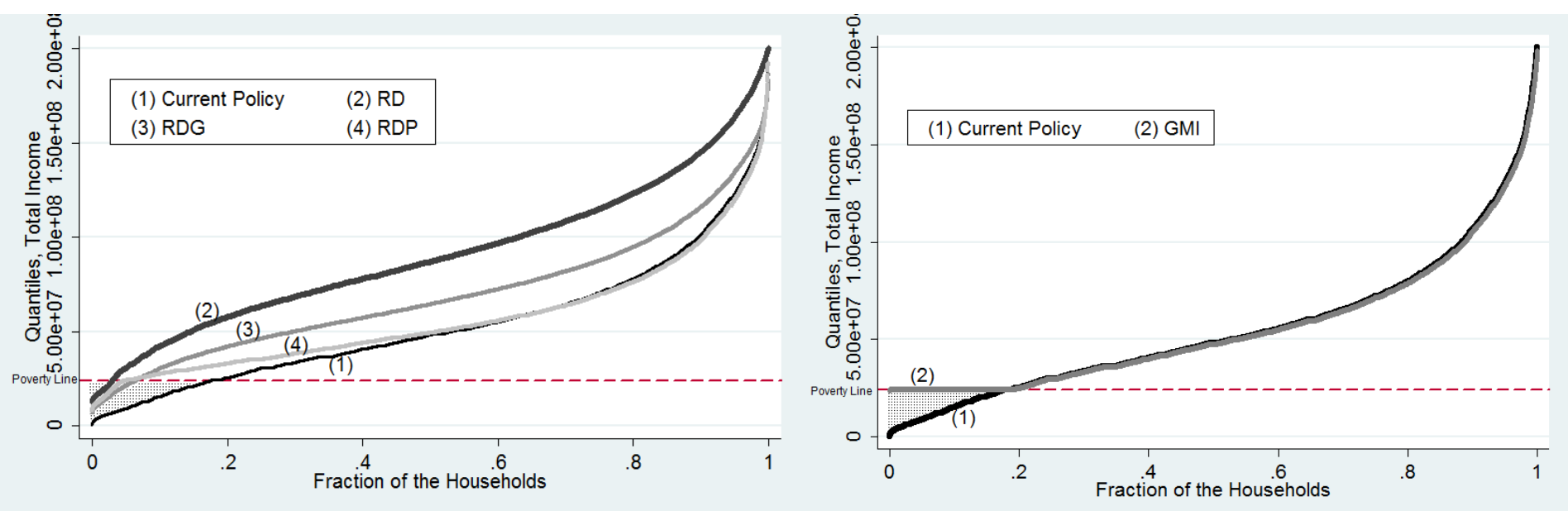
In Figures 2 and 3, the quantile functions indicate that households below the poverty line (horizontal dashed line is the poverty line before the policy) are significantly shifted out of the poverty gap area (dotted area) after the redistribution of the rents and the extra taxation (RD).

The changes in the shape of the quantile figure indicates a more equal distribution of income after the RD, RDG, and RDP policies, though the RD policy appears to be the most effective as it demonstrates the best distribution. Nonetheless, a portion of the population is still below the poverty line. By contrast, after the GMI policy, all poor households are above the poverty line, while the rest of the GMI function appears static on the current policy function, showing that almost no changes in the income distribution of the households above the poverty line have been made after the GMI policy.

In addition to the poverty measurements, we investigate the effects of resource rents direct distribution policy on the income distribution patterns. Following Lerman and Yitzhaki (1985) and Stark et al. (1986), we estimate the GINI decomposition by defining the GINI (G) coefficient as in Eq.5:

$G=\int_{a}^{b} F(y)[1-F(y)] d y$

Where $y$ is the total income and $F$ is a cumulative distribution of income. This GINI coefficient can be shown as a share of income source $k$ (for example, income from salary or from rents) in total income $\left(S_{k}\right)$, the GINI of income source $\left(G_{k}\right)$, and the correlation of income source GINI with the total income GINI $\left(R_{k}\right)$.

$G=\sum_{k=1}^{k} S_{k} G_{k} R_{k}$

We examine three main sources of income that are taxed by the State - salary income, selfemployed income and resource rents. The marginal effect of income sources on the total GINI can be obtained from:

$\frac{S_{k} G_{k} R_{k}}{G}-S_{k}$

The results are presented in Tables 3 and 4 . Table 3 indicates that after the RD policy, income inequality decreases from 0.44 to 0.29 , which is comparable to the pattern of a developed country's income distribution. Inequality is more significant in the income source from rents, which is 0.97 before policy implementation. However, after the rent distribution and extra taxation, the inequality in rents income decreases to 0.29 as well. The percent changes explain 
the marginal effects of the income source on the GINI coefficient. For example, if selfemployed income increases by $1 \%$ in the current policy, the GINI coefficient increases by $5 \%$. Bootstrap results show that our findings are within the 95\% confidence level.

Table 3. GINI decomposition for three income sources in the rural area

\begin{tabular}{|c|c|c|c|c|c|c|c|c|c|}
\hline \multicolumn{6}{|c|}{ GINI Decomposition } & \multicolumn{4}{|c|}{ Bootstrap } \\
\hline Rural & Source & $S_{k}$ & $\mathrm{G}_{\mathrm{k}}$ & $\mathrm{R}_{\mathrm{k}}$ & $\begin{array}{c}\% \\
\text { Change }\end{array}$ & Observed & Std. Err. & {$[95 \% \mathrm{Cc}$} & Interval] \\
\hline \multirow{4}{*}{$\begin{array}{c}\text { Current } \\
\text { policy }\end{array}$} & Salary Income & 0.41 & 0.695 & 0.69 & -0.004 & -.0038 & .0047 & -.0133 & .0057 \\
\hline & Self-employed & 0.35 & 0.784 & 0.64 & 0.05 & .0504 & .0052 & .0399 & .0609 \\
\hline & Rents & 0.03 & 0.970 & 0.48 & 0.002 & .0019 & .0016 & -.0013 & .0051 \\
\hline & Total income & & 0.441 & & & & & & \\
\hline \multirow{4}{*}{$\begin{array}{c}\text { RD } \\
\text { policy }\end{array}$} & Salary Income & 0.16 & 0.695 & 0.49 & 0.03 & .0295 & .0030 & .0234 & .0356 \\
\hline & Self-employed & 0.14 & 0.784 & 0.56 & 0.07 & .0707 & .0044 & .0618 & .0796 \\
\hline & Rents & 0.61 & 0.295 & 0.84 & -0.09 & -.0891 & .0039 & -.0971 & -.0810 \\
\hline & Total income & & 0.290 & & & & & & \\
\hline \multirow{4}{*}{$\begin{array}{l}\text { RDG } \\
\text { policy }\end{array}$} & Salary Income & 0.22 & 0.695 & 0.55 & 0.05 & .050 & .003 & .043 & .057 \\
\hline & Self-employed & 0.19 & 0.784 & 0.60 & 0.09 & .096 & .005 & .086 & .106 \\
\hline & Rents & 0.45 & 0.299 & 0.71 & -0.15 & -.148 & .003 & -.153 & -.142 \\
\hline & Total income & & 0.315 & & & & & & \\
\hline \multirow{4}{*}{$\begin{array}{l}\text { RDP } \\
\text { policy }\end{array}$} & Salary Income & 0.36 & 0.695 & 0.50 & 0.008 & .008 & .005 & -.003 & .019 \\
\hline & Self-employed & 0.30 & 0.784 & 0.56 & 0.09 & .086 & .007 & .071 & .099 \\
\hline & Rents & 0.15 & 0.815 & 0.21 & -0.08 & -.081 & .003 & -.088 & -.074 \\
\hline & Total income & & 0.341 & & & & & & \\
\hline \multirow{4}{*}{$\begin{array}{c}\text { GMI } \\
\text { policy }\end{array}$} & Salary Income & 0.40 & 0.695 & 0.62 & 0.04 & .043 & .005 & .0315 & .054 \\
\hline & Self-employed & 0.34 & 0.784 & 0.63 & 0.09 & .094 & .005 & .0841 & .105 \\
\hline & Rents & 0.06 & 0.835 & -0.31 & -0.11 & -.110 & .003 & -.118 & -.103 \\
\hline & Total income & & 0.390 & & & & & & \\
\hline
\end{tabular}

Note: $\mathrm{S}_{\mathrm{k}}$ : resource share from the total income, $\mathrm{G}_{\mathrm{k}}$ : GINI coefficient of the income source, and $\mathrm{R}_{\mathrm{k}}$ : income source GINI correlation with the total GINI.

By distributing only the government resource rents (RDG), the GINI drops to 0.31 and the share of households' rent income compared to total households' income, on average, increases by $42 \%$ (from $3 \%$ under the current policy to $45 \%$ under the RDG policy). Furthermore, if just $3 \%$ of the resource rents is transferred to the households below the poverty line (RDP), the GINI coefficient significantly drops by $23 \%$ (from 0.44 under the current policy to 0.34 under the RDP policy). 
Contrary to the poverty results, the GMI policy is less successful in decreasing the GINI coefficient compared to the alternative policies. As a result, there is a tradeoff between addressing poverty and reducing inequality in our simulated policies ${ }^{14}$.

Table 4. GINI decomposition for three income sources in the urban area

\begin{tabular}{|c|c|c|c|c|c|c|c|c|c|}
\hline \multicolumn{6}{|c|}{ GINI Decomposition } & \multicolumn{4}{|c|}{ Bootstrap } \\
\hline \multirow{5}{*}{$\begin{array}{c}\text { Urban } \\
\begin{array}{c}\text { Current } \\
\text { policy }\end{array}\end{array}$} & \multirow{5}{*}{$\begin{array}{c}\text { Source } \\
\text { Salary Income } \\
\text { Self-employed } \\
\text { Rents } \\
\text { Total income }\end{array}$} & \multirow{2}{*}{$\begin{array}{c}S_{\mathrm{k}} \\
0.45\end{array}$} & \multirow{2}{*}{$\begin{array}{c}\mathrm{G}_{\mathrm{k}} \\
0.639\end{array}$} & \multirow{2}{*}{$\begin{array}{c}\mathrm{R}_{\mathrm{k}} \\
0.55\end{array}$} & \multirow{2}{*}{$\begin{array}{c}\% \\
\text { Change } \\
-0.05\end{array}$} & \multirow{2}{*}{$\begin{array}{c}\text { Observed } \\
-.049\end{array}$} & \multirow{2}{*}{$\begin{array}{c}\text { Std. Err. } \\
.005\end{array}$} & \multicolumn{2}{|c|}{ [95\% Conf. Interval] } \\
\hline & & & & & & & & -.060 & -.039 \\
\hline & & 0.27 & 0.826 & 0.54 & 0.04 & .037 & .007 & .021 & .053 \\
\hline & & 0.04 & 0.949 & 0.51 & 0.009 & .008 & .002 & .003 & .013 \\
\hline & & & 0.393 & & & & & & \\
\hline \multirow{4}{*}{$\begin{array}{c}\text { RD } \\
\text { policy }\end{array}$} & Salary Income & 0.22 & 0.639 & 0.46 & 0.02 & .018 & .003 & .011 & .025 \\
\hline & Self-employed & 0.14 & 0.826 & 0.49 & 0.07 & .068 & .006 & .056 & .081 \\
\hline & Rents & 0.50 & 0.275 & 0.73 & -0.13 & -.132 & .003 & -.140 & -.125 \\
\hline & Total income & & 0.276 & & & & & & \\
\hline \multirow{4}{*}{$\begin{array}{l}\text { RDG } \\
\text { policy }\end{array}$} & Salary Income & 0.29 & 0.639 & 0.49 & 0.009 & .009 & .005 & -.0003 & .020 \\
\hline & Self-employed & 0.18 & 0.826 & 0.51 & 0.07 & .069 & .007 & .053 & .085 \\
\hline & Rents & 0.34 & 0.290 & 0.59 & -0.15 & -.150 & .002 & -.155 & -.144 \\
\hline & Total income & & 0.306 & & & & & & \\
\hline \multirow{4}{*}{$\begin{array}{l}\text { RDP } \\
\text { policy }\end{array}$} & Salary Income & 0.41 & 0.638 & 0.49 & -0.02 & -.018 & .006 & -.031 & -.006 \\
\hline & Self-employed & 0.25 & 0.826 & 0.50 & 0.07 & .067 & .007 & .051 & .083 \\
\hline & Rents & 0.11 & 0.830 & 0.06 & -0.09 & -.090 & .003 & -.097 & -.083 \\
\hline & Total income & & 0.329 & & & & & & \\
\hline \multirow{4}{*}{$\begin{array}{c}\text { GMI } \\
\text { policy }\end{array}$} & Salary Income & 0.43 & 0.638 & 0.54 & -0.01 & -.011 & .006 & -.025 & .002 \\
\hline & Self-employed & 0.26 & 0.826 & 0.53 & 0.06 & .065 & .007 & .049 & .081 \\
\hline & Rents & 0.07 & 0.855 & -0.11 & -0.08 & -.087 & .003 & -.094 & -.079 \\
\hline & Total income & & 0.354 & & & & & & \\
\hline
\end{tabular}

In the urban areas, as is shown in Table 4, before the simulation, the GINI coefficient was 0.39. However it decreases to the more equal rate of 0.27 after transferring the resource rents (RD) and levying an $18 \%$ tax rate on the three sources of taxable incomes. The rents based income distribution is improved from 0.94 to 0.27 . The results are confirmed using the bootstrap method and all are within the 95\% confidence level. Using the RDG and RDP, the GINI coefficient decreases by $23 \%$ and $15 \%$, respectively, compared to the current policy. Moreover, distributing an amount of resource rents that is equal to 1\% of the GDP (GMI policy) to fill the

\footnotetext{
${ }^{14}$ In a more universal transfer, income inequality will decrease more. However, it is less likely to alleviate poverty. In contrast, a targeting policy such as the GMI can better empower lower income groups (targeted group), while it has no effect on the non-targeted groups (higher income group). In practice, the targeting policies are even less successful due to allocation inefficiencies and a lack of appropriate information about the poor. For debates on comparing targeted and universal transfers, see Segal (2011).
} 
total poverty gap can lead to a $10 \%$ reduction in the GINI, that is, from 0.39 (in the current policy) to 0.35 . In Table 5, we note that the reduction of income inequality is the result of fewer poor and fewer rich households after the policies.

For a better intuition of how the density shape changes after the policy of direct distribution of resource rents, we estimate the Epanechnikov kernel density functions (Epanechnikov, 1969) in Eq.8:

$\widehat{f_{h}}=\frac{1}{n} \sum_{i=1}^{n} K_{h}\left(x-x_{i}\right)$

here $K($.$) is the kernel and h$ is the bandwidth. The results are presented in Figures 4 and 5.

Figure 4. Kernel density and Lorenz curve of the rural households
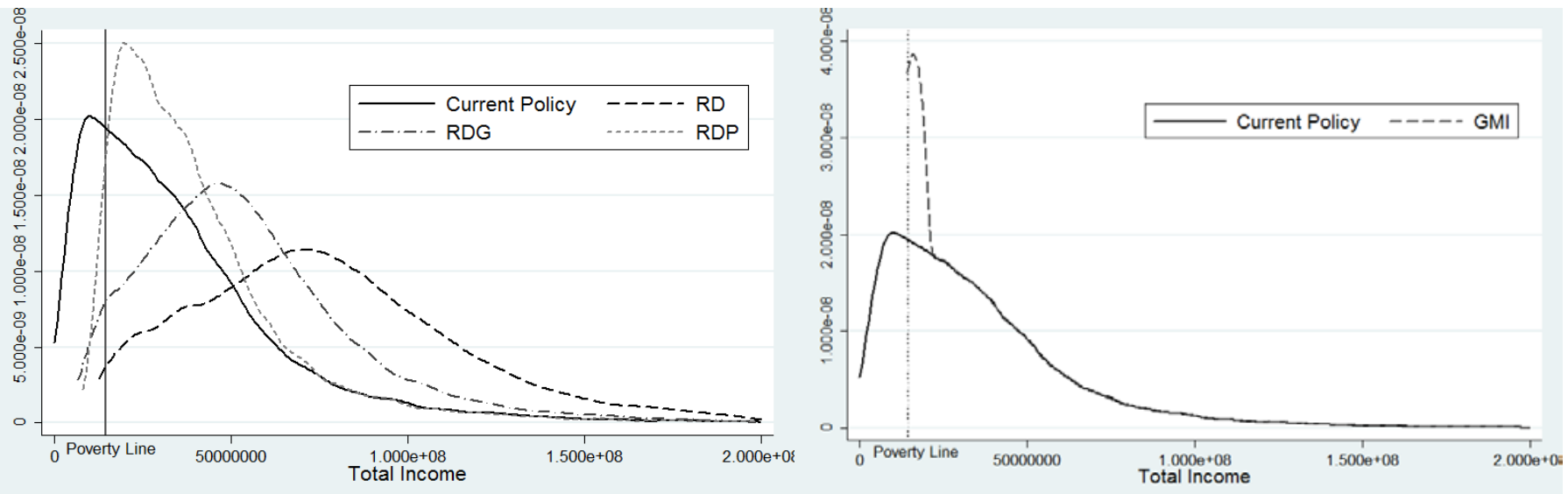

Figure 5. Kernel density and Lorenz curve of the urban households
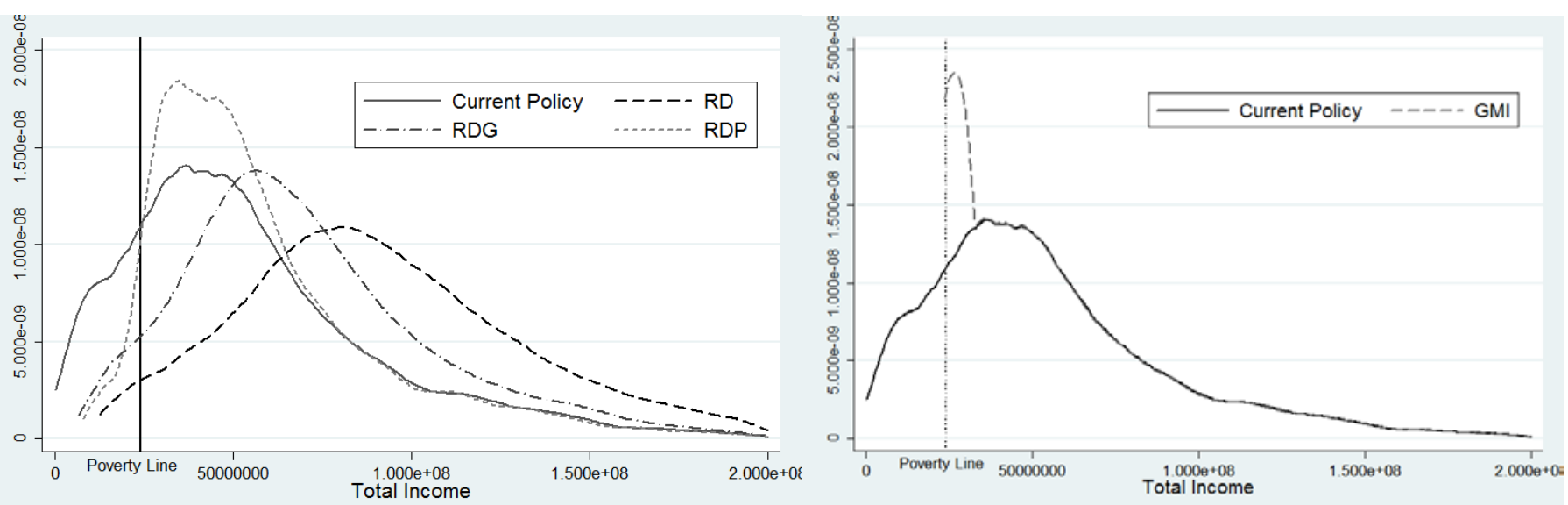

From the income density changes in Figure 4 it can be seen how the poor population has escaped from the poverty line by shifting to the right hand side of the figure after RD, RDG, and RDP policies. The peak of the total income in the rural households is below the poverty line before the distribution while it crosses the line after the policy implementation. Approximately 
$14 \%$ of the urban households cross the line after the policy. Income distribution is converting from a left skewed shape to more a bell shape and Lorenz curve is closer to the 45-degree line after the RD policy, which indicates a better distribution of total income.

Income distribution in urban households is better distributed than it is in rural households. However, graphically, it assumes a normal distribution curve after the RD policy as the density shifts to the right. The Lorenz curve is closer to the 45-degree line when using the simulated policy.

In both areas, with respect to the GMI kernel density function, the populations below the poverty line are crossing the poverty line, while the distribution of the income for higher income groups remains unchanged.

Table 5. Income distribution changes

\begin{tabular}{|c|c|c|c|c|c|c|c|}
\hline & $\begin{array}{l}\text { Policy } \\
\text { Status }\end{array}$ & 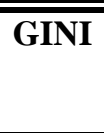 & $\begin{array}{l}\text { Sen's Social } \\
\text { Welfare } \\
\text { Changes }^{\mathrm{a}}\end{array}$ & $\begin{array}{c}\text { Share of } \\
\text { bottom } 10 \%\end{array}$ & $\begin{array}{c}\% \text { of bottom } \\
10 \% \text { from } \\
\text { median }\end{array}$ & $\begin{array}{l}\text { Share of } \\
\text { top } 10 \%\end{array}$ & $\begin{array}{c}\% \text { of bottom } \\
10 \% \text { from } \\
\text { median }\end{array}$ \\
\hline \multirow[t]{5}{*}{ Rural } & $\begin{array}{l}\text { Current } \\
\text { Policy }\end{array}$ & 0.44 & & 1.26 & 25.00 & 31.43 & 251.74 \\
\hline & $\mathrm{RD}$ & 0.29 & $167 \%$ & 2.77 & 41.62 & 21.76 & 176.54 \\
\hline & RDG & 0.31 & $83 \%$ & 2.58 & 40.83 & 23.85 & 188.67 \\
\hline & RDP & 0.34 & $34 \%$ & 3.36 & 48.56 & 27.45 & 210.62 \\
\hline & GMI & 0.39 & $12 \%$ & 3.79 & 50.80 & 30.18 & 252.24 \\
\hline \multirow[t]{5}{*}{ Urban } & $\begin{array}{l}\text { Current } \\
\text { Policy }\end{array}$ & 0.39 & $\mathrm{~b}$ & 1.47 & 31.46 & 28.90 & 233.08 \\
\hline & $\mathrm{RD}$ & 0.28 & $90 \%$ & 3.08 & 48.22 & 21.62 & 175.70 \\
\hline & RDG & 0.30 & $46 \%$ & 2.78 & 47.02 & 23.78 & 192.28 \\
\hline & RDP & 0.33 & $15 \%$ & 3.47 & 55.13 & 26.88 & 218.81 \\
\hline & GMI & 0.35 & $10 \%$ & 3.97 & 50.25 & 28.01 & 232.62 \\
\hline
\end{tabular}

a. In percentage. It shows how much social welfare is better off after the policies.

b. Welfare in urban area is $73 \%$ higher than the rural without considering the higher expenses in cities.

Considering distributional changes of the total household income in Table 5, the total rural and urban household welfare after the resource rents direct distribution policy (RD) increases by $167 \%$ and $90 \%$, respectively, compared to the welfare before the policy implementation. While the share of the lowest income decile increases twice, the richest share declines. These changes in income shares indicate that the inequality reduction is the result of the changes in the poor and the rich populations together, i.e., the increase in society’s middle income class. 
Reduced poverty rates, equal income distribution and welfare enhancement after the distribution of resource rents can increase public satisfaction and reduce the risk of internal conflict, political instability and terrorism. The welfare increase combined with approximately $98 \%$ of the income winners make the policy more acceptable to the public despite an $18 \%$ direct income tax levied on household income. The policy scenario means that the government budget constraint remains unchanged and that as a result the possible negative effects of the budget deficit are avoided. Additionally, it makes the policy more acceptable to governments by allowing them to realize the same level of income amount from the tax source. Moreover, there are possible positive effects due to changes in the revenue structure of the government budget from tax windfalls. It not only motivates people to engage in policy discussions, but it also makes the State more responsible and accountable for its expenditures.

\section{Conclusion}

One of the transmission channels of the resource curse is through increasing income inequality and poverty, particularly in ethnically divided societies (Fum and Hodler, 2010). The Iranian economy, which is significantly dependent on resource rents, is an example of this nexus. Our impulse response and variance decomposition analyses also provide empirical evidence at the macro level regarding the positive associations and interconnections between oil rents and the GINI index in Iran. Identifying the rents-induced inequality at the national level leads to a key question for policy makers. How can the painful and costly effects of inequality in a renter economy be controlled?

There has been much interest in addressing the resource curse, thus suggesting the direct transfer of resource rents to the population. More often, however, such policy recommendations are based on descriptive explanations. We use rich survey-based data of more than 140,000 individuals in Iranian urban and rural areas and simulate the inequality and poverty effects of the direct rents distribution and the taxation policy. In our empirical analysis, we compare this proposal with three other alternatives and find that the direct distribution of resource rents and subsequent taxation proves to be the strongest moderator of income inequality and poverty.

Our findings show that any transfer policy using natural resource rents will decrease income inequality and poverty. Universal transfers such as the resource dividend (RD) policy are more likely to be effective in addressing income inequality than are targeted policies such as the guaranteed minimum income (GMI) policy. However, the latter seems to be more successful in eradicating poverty. Therefore, using the appropriate policy depends on the policy makers' 
objective. Finally, the resource dividend policy most likely enhances total social welfare and thus would be better supported by the public than alternative policies because of the higher share of income winners.

\section{References}

Alesina, A., Glaeser, E., 2004. Fighting Poverty in the U.S. and Europe: a World of Difference. Oxford University Press, Oxford.

Bjorvatn, K., Farzanegan, M.R., 2013. Demographic transition in resource rich countries: a blessing or a curse? World Development 45, 337-351.

Bjorvatn, K., Farzanegan, M.R., Schneider, F., 2013. Resource curse and power balance: evidence from Iran. Review of Middle East Economics and Finance 9, 133-158.

Bjorvatn, K., Farzanegan, M.R., Schneider, F., 2012. Resource curse and power balance: evidence from oil-rich countries. World Development 40, 1308-1316.

Bjorvatn, K., Selvik, K., 2008. Destructive competition: factionalism and rent-seeking in Iran. World Development 36, 2314-2324.

CBI, 2014. Economic Time Series Database. Economic Research and Policy Department, Central Bank of Iran, Tehran.

Chamarbagwala, R., Moran, H. E., 2011. The human capital consequences of civil war: evidence from Guatemala. Journal of Development Economics 94, 41 -61.

Clements, M. P., Hendry, D.F., 1995. Forecasting in cointegrated systems. Journal of Applied Econometrics 10, 127-146.

Clemons, S., 2003. Sharing, Alaska-Style. New York Times, 9 April. Available at: http://www.nytimes.com/2003/04/09/opinion/sharing-alaska-style.html

Collier, P., Hoeffler, A., 1998. On economic causes of civil war. Oxford Economic Papers 50, 563-573.

Collier, P., Hoeffler, A., 2004. Greed and grievance in civil war. Oxford Economic Papers 56, 563-595.

Collier, P., Elliott, V. L., Hegre, H., Hoeffler, A. ., Reynal-Querol, M., Sambanis, N., 2003. Breaking the conflict trap: civil war and development policy. World Bank Policy Research Report. New York: Oxford University Press.

Dizaji, S. F, Bergeijk, P. AG van., 2013. Potential early phase success and ultimate failure of economic sanctions: A VAR approach with an application to Iran. Journal of Peace Research 50(6), 721-736. 
Dizaji, S.F., Farzanegan, M.R., 2014. Political institutions and government spending behavior in Iran. MAGKS Papers 03-2014, Marburg.

Doan, T., 2000. RATS version 5 User’s Guide. Estima, Evanston.

Engle, R. F, Yoo, B. S., 1987. Forecasting and testing in co-integrated systems. Journal of Econometrics 35, 143-159.

Epanechnikov, V.A., 1969. Non-parametric estimation of a multivariate probability density. Theory of Probability and its Applications 14, 153-158.

Farzanegan, M.R., 2014. Can oil-rich countries encourage entrepreneurship? ‘yes', ‘no’ but not 'perhaps'. MAGKS Papers 06-2014, Marburg.

Farzanegan, M.R., 2013. Oil and the future of Iran: a blessing or a curse? Legatum Institute Future of Iran series, London.

Farzanegan, M.R., 2012. Military spending and economic growth: the case of Iran. Defense and Peace Economics, iFirst Article, 1-23, doi: http://dx.doi.org/10.1080/10242694.2012.723160

Farzanegan, M.R., 2011. Oil revenue shocks and government spending behavior in Iran. Energy Economics 33, 1055-1069.

Farzanegan, M.R., Lessmann, C., Markwardt, G., 2013. Natural-resource rents and internal conflicts - can decentralization lift the curse? CESifo Working Paper No. 4180, Munich.

Farzanegan, M.R., Markwardt, G., 2009. The effects of oil price shocks on the Iranian economy. Energy Economics 31, 134-151.

Frankel, J.F., 2010. The natural resource curse: a survey. NBER working paper, no. 15836.

Fum, R. M., Hodler, R., 2010. Natural resources and income inequality: The role of ethnic divisions. Economics Letters 107, 360-363.

Gylfason, T., 2001. Natural resources, education, and economic development. European Economic Review 45, 847-859.

Hodler, R., 2006. The curse of natural resources in fractionalized countries. European Economic Review 50, 1367-1386.

Hoffman, D. L., Rasche, R.H., 1996. Assessing forecast performance in a cointegrated system. Journal of Applied Econometrics 11, 495-517.

Johansen, S., 1995. Likelihood-based Inference in Cointegrated Vector Autoregressive Models, Oxford: Oxford University Press.

Johansen, S., Juselius, K., 1990. Maximum likelihood estimation and inference on cointegration-with applications to the demand for money. Oxford Bulletin of Economics and Statistics 52, 169-210. 
Lerman, R. I., and S. Yitzhaki, 1985. Income inequality effects by income source: A new approach and applications to the United States. Review of Economics and Statistics 67, 151-156.

Lütkepohl, H., 1991. Introduction to Multiple Time Series Analysis, New York: SpringerVerlag.

Mehlum, H., Moene, K., Torvik, R., 2006. Institutions and resource curse. Economic Journal 116, 1-20.

Mohaddes, K., Pesaran, H., 2013. One hundred years of oil income and the Iranian economy: a curse or a blessing? CESifo Working Paper Series 4118, Munich.

Montalvo, J. G., Reynal-Querol, M., 2005. Ethnic polarization, potential conflict, and civil wars. The American Economic Review 95, 796-816.

Naka, A., Tufte, D., 1997. Examining impulse response functions in cointegrated systems. Applied Economics 29, 1593-1603.

Palley, T. I., 2003. Combating the natural resource curse with citizen revenue distribution funds: oil and the case of Iraq. FPIF Special Report. Available at : http://www.thomaspalley.com/docs/articles/economic_development/natural_resources_c urse.pdf

Pesaran, M. H., Shin, Y., 1998. Generalised impulse response analysis in linear multivariate models. Economics Letters 58, 17-29.

Ross, M., 2012. Oil curse: how petroleum wealth shapes the development of nations. Princeton University Press.

Ross, M. L., 2004. What do we know about natural resources and civil war? Journal of Peace Research 41, 337-356.

Sala-i-Martín, X. \& Subramanian, A., 2003. Addressing the natural resource curse: an illustration from Nigeria. National Bureau of Economic Research, Working Paper 9804.

Salehi-Isfahani, D., 2009. Poverty, inequality, and populist politics in Iran. The Journal of Economic Inequality 7, 5-28.

Sandbu, M. E., 2006. Natural wealth accounts: a proposal for alleviating the natural resource curse. World Development 34, 1153-1170.

Segal, P., 2011. Resource rents, redistribution, and halving global poverty: the resource dividend. World Development 39, 475-489.

Shemyakina, O., 2011. The effect of armed conflict on accumulation of schooling: results from Tajikistan. Journal of Development Economics 95, 186-200. 
Sims, C. A., 1980. Macroeconomics and reality. Econometrica 48, 1-48.

Sims, C. A., Stock, J., Watson, M., 1990. Inference in linear time series models with some unit roots. Econometrica 58, 113-144.

Stark, O., J. E. Taylor, and S. Yitzhaki, 1986. Remittances and inequality. Economic Journal 96, 722-740.

Torvik, R., 2002. Natural resources, rent-seeking and welfare. Journal of Development Economics 67, 455-470.

van der Ploeg, F., 2011. Natural resources: curse or blessing? Journal of Economic Literature 49, 366-420.

van Wijenbergen, S., 1984. Inflation, employment, and the Dutch disease in oil exporting countries: a short-run disequilibrium analysis. Quarterly Journal of Economics 99, 233250. 